\title{
PERAN KONFLIK PEKERJAAN-KELUARGA TERHADAP KUALITAS HIDUP DENGAN STRES SEBAGAI MEDIATOR PADA WANITA PERAN GANDA
}

\author{
Agita Presilia $^{1}$, Rismiyati E Koesma ${ }^{2}$ dan Zamralita $^{3}$ \\ ${ }^{1}$ Program Studi Magister Psikologi, Universitas Tarumanagara, Jakarta \\ Email: agita.presilia@gmail.com \\ ${ }^{2}$ Fakultas Psikologi, Universitas Tarumanagara, Jakarta \\ Email: ristetty@gmail.com \\ ${ }^{3}$ Fakultas Psikologi, Universitas Tarumanagara ,Jakarta \\ Email: zamralita@fpsi.untar.ac.id
}

\begin{abstract}
ABSTRAK
Konflik pekerjaan-keluarga banyak dialami pada wanita peran ganda karena mengalami ketidakseimbangan dalam menjalankan tuntutan dalam pekerjaan maupun dalam keluarga. Hal ini akan mempengaruhi kepuasan wanita peran ganda dan mengalami dampak negatif dalam kehidupan sehingga akan menurunkan kualitas hidupnya. Namun, didapatkan hasil yang berbeda, di mana hubungan konflik pekerjaan-keluarga terhadap kualitas hidup dinyatakan tidak cukup kuat, sehingga dalam penelitian ini menggunakan variabel mediator yaitu stres. Konflik pekerjaan-keluarga dapat menyebabkan stres pada wanita peran ganda, sehingga akan mempengaruhi kualitas hidupnya. Oleh karena itu, penelitian ini bertujuan untuk melihat peran konflik pekerjaan-keluarga terhadap kualitas hidup dengan stres sebagai mediator. Populasi dalam penelitian ini adalah karyawan wanita di Kementerian X yang sudah menikah dan juga sudah memiliki anak. Teknik pengambilan sampel yang digunakan adalah purposive sampling dan juga dilanjutkan melalui teknik convenience sampling. Jumlah sampel dalam penelitian ini adalah 183 karyawan wanita peran ganda. Penelitian ini menggunakan tiga alat ukur, yaitu Multdimensional Scale of Work-Family Conflict, World Health Organizational Quality of Life (WHOQOL-BREF), dan juga skala stres umum. Pengujian model dilakukan dengan menggunakan Structural Equation Modelling (SEM) menggunakan LISREL 8.70. Hasil pengujian model menunjukkan bahwa stres dapat berperan sebagai mediator dengan nilai $p$-value $<0.05$, dan RMSEA <0.08, dan dapat memediasi secara parsial pada konflik pekerjaan-keluarga terhadap kualitas hidup. Hasil nilai standardized solution untuk peran konflik pekerjaan-keluarga terhadap kualitas hidup yang awalnya hanya -0.66 menjadi -0.83 . Dengan kata lain, hasil ini mengindikasikan bahwa individu yang mengalami konflik pekerjaan-keluarga, ketika mengalami stres, akan memiliki kualitas hidup yang lebih rendah.
\end{abstract}

Kata Kunci: konflik pekerjaan-keluarga, kualitas hidup, stres, mediator, dan wanita peran ganda

\begin{abstract}
Work-family conflicts are mostly experienced by multiple roles women because they experience an imbalance in carrying out demands at work and in the family. This will affect the satisfaction of multiple roles women who experience negative impacts that will lower their quality of life. However, different results were obtained, where the relationship between work-family conflict and quality of life was declared not strong enough, therefore, this study used stress as a mediator variable. Work-family conflict can cause stress in multiple roles women, so it will affect the quality of life. Therefore, this study aims to look at the role of work-family conflict on the quality of life with stress as a mediator. The population in this study were female employees in Ministry $X$ who were married and had children. The sampling technique used was purposive sampling and also continued through convenience sampling technique. The number of samples in this study were $183 \mathrm{~b}$ employees who were multiple roles women. This study used three measuring instruments, namely the Multdimensional Scale of Work-Family Conflict, World Health Organizational Quality of Life (WHOQOL-BREF), and also the general stress scale. Model testing was carried out using Structural Equation Modeling (SEM) using LISREL 8.70. The results of the model testing show that stress can act as a mediator with p-value of $<0.05$, and RMSEA of $<0.08$, and can partially mediate work-family conflicts with quality of life. The result of the standardized solution value for the role of work-family conflict on quality of life decreased from -0.66,
\end{abstract}


to -0.83. In other words, these results indicate that individuals who experience work-family conflict, when experiencing stress, will have lower quality of life.

Keyword: work-family conflicts quality of life, stress, mediators, and multiple role women

\section{PENDAHULUAN \\ Latar Belakang}

Meningkatnya tuntutan hidup akibat perubahan zaman, menggugah serta mendorong kalangan wanita untuk mencari pekerjaan guna menambah penghasilan agar dapat lebih menunjang kebutuhan rumah tangga. Pada beberapa dekade sebelumnya, kalangan wanita lebih banyak bertanggung jawab untuk mengurus rumah tangga. Budaya kolektivitas yang tinggi dan masih menekankan orientasi gender, wanita dihadapkan tuntutan dan tanggung jawab dalam berkeluarga dan melakukan seluruh perannya dalam berkeluarga (Korabik, Aycan, \& Ayman, 2017). Dalam perkembangan masyarakat saat ini, selain menjalani peran sebagai ibu rumah tangga, wanita juga dituntut untuk bekerja di luar rumah sebagai tenaga profesional. Oleh karena itu, tugas dan tanggung jawab wanita dewasa menjadi semakin besar.

Data statistik internasional melaporkan peningkatan jumlah pekerja dari tahun ke tahun. International Labour Organization atau ILO memaparkan bahwa wanita yang terlibat dalam pekerjaan semakin tinggi setiap tahunnya sejak tahun 1980 hingga 2008 ini, yaitu dari yang memiliki persentase 50.2\% menjadi 51.7\% (ILO, 2011). Pada tahun 2014, data ILO juga kembali melakukan peningkatan pada presentase wanita yang bekerja di Indonesia yang mencapai 53.4\%. ILO juga memiliki prediksi bahwa angka tersebut akan semakin meningkat pada tahun 2019 sehingga wanita terus dapat berperan dalam peluang dunia kerja (ILO, 2015). Pada data statistik nasional, terutama di Indonesia, tercatat pula perubahan jumlah wanita bekerja dari tahun ke tahun. BPS juga memaparkan bahwa terjadinya peningkatan dari tahun 2012 hingga tahun 2015, yaitu dari 43 juta wanita yang bekerja meningkat menjadi 45.6 juta karyawan wanita. Data terakhir di BPS pada tahun 2017 juga menunjukkan jumlah karyawan wanita lebih banyak yang bekerja karena mencapai angka $60.17 \%$, dan yang tidak bekerja hanya memiliki persentase $39.83 \%$. Hal ini dapat menunjukkan bahwa wanita mulai memiliki kesempatan yang sama dengan berperan aktif dalam dunia pekerjaan di Indonesia.

Wanita memutuskan untuk bekerja dengan memiliki tujuannya masing-masing, seperti kebutuhan finansial, sarana aktualisasi diri, dan juga tempat untuk bergaul dan juga memperluas wawasan. (Hermayanti, 2014). Dengan peran pengasuhan terhadap keluarga, namun di satu sisi mereka memiliki keterlibatan dengan pekerjaan dan banyaknya tuntutan, sehingga dapat membuat wanita bekerja mengalami konflik. Peran dan pembagian tugas kerja yang tidak seimbang menjadikan wanita sulit dalam menjalani kehidupannya, karena wanita juga dituntut untuk mengambil keputusan dalam kedua perannya (Ismanto \& Suhartini, 2014).

Pada dasarnya, konflik peran ganda menurut Gibson (dalam Wirakristama, 2011) terdiri dari tiga jenis, yaitu konflik peran itu sendiri (person role conflict), konflik intra peran (intra role conflict), dan konflik antar peran (inter role conflict), namun dalam penelitian akan dibahas mengenai konflik antar peran. Dalam penelitian ini, konflik antar peran yang akan dibahas adalah peran pekerjaan-keluarga karena semakin meningkatnya perubahan demografi terkait dengan wanita bekerja. Wanita karir yang menikah dan telah memiliki anak, cenderung mengalami konflik 
dikarenakan wanita karir memiliki tanggung jawab dan komitmen yang lebih terhadap pekerjaan dan keluarga sehingga mereka diharuskan untuk memiliki waktu yang lebih banyak untuk memenuhi kedua tanggung jawab tersebut. Ketika berada dalam keluarga, wanita memiliki peran sebagai istri, sebagai pendidik untuk anak-anaknya, dan juga sebagai ibu rumah tangga (Martina, 2012). Konflik pekerjaan-keluarga dapat menyita waktu, menguras energi, tenaga dan juga pikiran, terutama pada wanita yang sudah memiliki anak dan masih membutuhkan perhatian dari Ibunya.

Konflik pekerjaan-keluarga atau work family conflict diartikan sebagai sebuah bentuk konflik peran di mana ranah pekerjaan dan keluarga memberi tekanan secara bersamaan yang saling bertentangan (Greenhaus \& Beutell, 1985). Menurut Greenhaus dan Beutell (dalam Carlson et al., 2000), work-family conflict merupakan suatu kondisi yang menimbulkan konflik antar peran yang diemban namun terdapat tuntutan peran dari work dan family yang saling bertentangan satu sama lain. Greenhaus dan Beutell (1985) menjelaskan bahwa konflik pekerjaan-keluarga memiliki tiga dimensi, yaitu, a) time-based conflict (konflik karena waktu), yaitu waktu yang telah disediakan untuk beraktivitas dalam salah satu peran tidak dapat dibagi untuk peran yang lain, b) strain-based conflict (konflik karena ketegangan), yaitu ketegangan yang muncul akibat salah satu peran dan mengganggu peran lainnya, dan c) behaviour-based conflict (konflik karena perilaku, yaitu perubahan bentuk tingkah laku yang berbeda akibat salah satu peran dan mengganggu peran lainnya. Selain itu, konflik pekerjaan-keluarga memiliki dua arah atau bi-directional, yakni family interferes with work, dan work interferes with family.

Apollo dan Cahyadi (2012) memaparkan bahwa konflik pekerjaan-keluarga juga dapat dipengaruhi oleh aspek internal maupun aspek eksternal. Aspek internal, misalnya, persoalan yang muncul dalam pribadi individu, yang meliputi motivasi untuk mencapai aktualisasi diri ataupun kebutuhan finansialnya, dan juga aspek eskternal yang meliputi dukungan suami, kehadiran anak dalam keluarga, dan juga hambatan dalam pekerjaan. Ragam konflik ini dapat memicu timbulnya permasalahan dalam keluarga, khususnya pada hubungan suami isteri, salah satunya yaitu interaksi yang berakibat pada kesalahpahaman serta dapat berujung dengan perceraian (Sidhawati \& Syarifah, 2014).

Barling dan Macewen (dalam Poms et al., 2016) memaparkan bahwa konflik pekerjaan-keluarga dapat mengancam kehidupan individu, seperti mengurangi kualitas hidup pada diri karyawan dan hubungan pada pernikahan. Tidak tercapainya kebahagiaan pada wanita karir yang berstatus menikah, secara terus-menerus akan berdampak pada tingginya stres dan depresi. Sedangkan, pada organisasi, konflik dapat membuat motivasi kerja dan komitmen karyawan menurun (Poelmans \& Stevens, 2001). Apabila peristiwa ini terjadi dan berlangsung terus menerus, tentu akan dapat memicu ketidakpuasan, baik dalam peran pekerjaan, maupun dalam peran keluarga. Ketidakpuasan akan dalam pekerjaan dan keluarga merupakan permasalahan besar bagi wanita dan dapat berpengaruh terhadap kualitas hidupnya.

Kualitas hidup wanita dalam keluarga adalah hal yang sangat penting. Wanita atau khususnya yang telah menjadi seorang Ibu adalah ujung tombak yang menjadi kunci keberhasilan dari suatu keluarga dan yang dapat memberikan dampak positif maupun negatif terhadap anggota keluarga lainnya, terutama anak. Ibu juga merupakan 
penentu baik atau buruknya seorang anak. Syahid (2015) mengatakan bahwa sosok Ibu memiliki tanggung jawab yang sangat besar dalam mendidik dan membimbing anak-anaknya. Kepribadian Ibu juga sangat berperan dalam menentukan masa depan sang anak. Ibu diharapkan memiliki kehidupan yang berkualitas agar menciptakan putra maupun putri yang berkualitas. Oleh karena itu, kualitas kehidupan para wanita yang berperan ganda penting untuk dikaji dan ditingkatkan agar terciptanya keturunan dan generasi yang berkualitas (Kementrian Pemberdayaan Perempuan dan Perlindungan Anak Republik Indonesia, 2016).

Menurut WHO (1996), kualitas hidup merupakan persepsi individual mengenai kehidupan dalam konteks budaya dan sistem nilai yang berlaku di tempat tinggalnya yang berhubungan dengan harapan dan standar hidup. Kualitas hidup dalam WHOQOL-BREF memiliki empat aspek yaitu kesehatan fisik, psikologis, hubungan sosial dan juga hubungan dengan lingkungan yang dapat dipengaruhi oleh faktor lingkungan, faktor pekerjaan, faktor keluarga, dan faktor personal seperti keadaan fisik atau psikologis (Power dalam Lopez \& Snyder, 2003).

Penelitian Hultman, Hemlin dan Hornquist (2006) menjelaskan bahwa wanita yang bekerja memiliki kualitas hidup yang lebih baik, jika dibandingkan dengan individu yang tidak bekerja. Kualitas hidup masing-masing individu berbeda, tergantung bagaimana individu tersebut menilai dirinya, melalui pekerjaan, keluarga, maupun teman-temannya. Apollo dan Cahyadi (2012) mengungkapkan kualitas hidup yang rendah dapat disebabkan oleh banyak faktor, seperti adanya rasa tertekan, kurang adanya dukungan suami, konflik kehadiran anak, tingginya tuntutan dan masalah dalam pekerjaan, hubungan antar anggota keluarga yang kurang harmonis, tingginya kebutuhan finansial dan tidak tercapainya aktualisasi diri. Oleh karena itu, ketika wanita mengalami tingginya tuntutan pekerjaan dan keluarga, maka akan mempengaruhi kualitas hidupnya.

Kadir (2011) mengatakan bahwa ketika konflik peran ganda semakin tinggi maka kualitas hidup individu akan cenderung rendah. Greenhaus, Collins, dan Shaw (2003) juga menemukan bahwa individu yang menghabiskan lebih banyak waktu dalam pekerjaan daripada keluarga, akan memiliki kualitas hidup yang rendah, dan sebaliknya, individu yang menghabiskan waktu lebih banyak dalam keluarga daripada di tempat kerja melaporkan kualitas hidup yang lebih tinggi.

Pada penelitian yang dilakukan oleh Rice et al. (1992) kualitas hidup tidak berhubungan langsung dengan konflik pekerjaan-keluarga namun ditentukan oleh variabel lainnya, yaitu kualitas kehidupan kerja dan kualitas kehidupan keluarga. Hubungan konflik pekerjaan-keluarga juga memiliki hubungan yang negatif dengan kualitas hidup, namun juga membutuhkan variabel lain sebagai mediator dari domain kualitas hidup dikarenakan konflik pekerjaan-keluarga tidak memiliki hubungan yang langsung dengan kualitas hidup (Rice et. al, 1992). Selain itu, penelitian yang mempertimbangkan peranan atau pun hubungan konflik pekerjaan-keluarga dengan kualitas hidup masih sangat jarang. Beberapa penelitian cenderung mengaitkan konflik pekerjaan-keluarga dengan kualitas kehidupan kerja. Sedangkan, pada kenyataannya, konflik kerja-keluarga juga memiliki keterkaitan dengan kualitas kehidupan individu di luar dari ranah pekerjaannya. 
Menurut Baron dan Kenny (1986), ketika terdapat dua variabel yang diragukan hubungannya, maka peneliti dapat memberikan satu variabel lain yang memiliki hubungan dengan satu atau kedua variabel utama tersebut. Keterkaitan antara dua fenomena terkadang tidak hadir dalam bentuk langsung, karena keterkaitan tersebut diperantarai oleh fenomena lainnya (Urbayatun \& Widhiarso, 2012). Oleh karena itu, peneliti tertarik untuk mencari variabel perantara atau variabel intervening untuk menjadi penghubung antara konflik pekerjaan-keluarga dengan kualitas hidup, yaitu stres sebagai variabel mediator. Stres sebagai variabel mediator tentunya memiliki hubungan dengan dua variabel dalam penelitian ini, yakni konflik pekerjaan-keluarga dan kualitas hidup.

Hayasaka, Nakamura, Yamamoto, dan Sasaki (2007) mengungkapkan bahwa psychological distress level lebih sering dialami oleh wanita yang telah bekerja dibandingkan wanita yang tidak bekerja. Sama halnya dengan apa yang dikemukakan oleh Apperson et al. (2002) bahwa konflik pekerjaan-keluarga juga akan berpengaruh terhadap kesehatan para karyawan. Konflik pekerjaan-keluarga juga dimanifestasikan terkait dengan kesehatan yang buruk, mengkonsumsi alkohol, dan juga tingkat stres yang tinggi. Poms et al. (2016) juga menambahkan bahwa stres dalam konflik kerjakeluarga juga diketahui dapat meningkatkan risiko masalah kesehatan fisik dan mental, baik dalam tahap akut maupun kronis.

Menurut Hawari (2008), stres merupakan respon tubuh yang tidak spesifik terhadap kebutuhan tubuh yang terganggu, yang tidak dapat dihindari setiap individu. Keadaan stres ini dapat menimbulkan perubahan secara fisiologis, psikologis dan perilaku pada individu yang dapat mengakibatkan munculnya penyakit pada individu. Pada variabel stres, domain stres menjadi tiga domain, terkait fisik, psikologis, dan perilaku (Poms, et al., 2016). Goliszek (2005) juga memaparkan bahwa ketika individu sudah mengalami stres, hal tersebut akan menimbulkan, (1) gejala fisik, (2) gejala psikologis, dan (3) gejala perilaku. Penelitian yang dilakukan oleh Ardila dan Sulistyaningsih (2014) mengatakan adanya hubungan yang kuat dan positif bahwa terjadi korelasi antara tingkat stres dengan kualitas hidup. Hal ini juga sejalan dengan penelitian yang dilakukan oleh Putri, Kholis, dan Ngestiningsih (2018) bahwa hubungan tingkat stres dan kualitas hidup individu juga berkorelasi secara signifikan dan negatif. Semakin tinggi tingkat stres individu, maka akan semakin buruk pula kualitas hidup individu tersebut. Sejalan dengan penelitian Koezier (2010), stres juga mampu mengubah persepsi individu, kepuasan, dan kualitas hidup. Berdasarkan pemaparan di atas, peneliti dapat menyatakan bahwa stres cenderung dialami oleh wanita peran ganda yang mengalami konflik pekerjaan-keluarga sehingga digunakan sebagai variabel mediator. Stres juga akan menghubungkan konflik pekerjaankeluarga dengan kualitas hidup.

\section{Rumusan Masalah}

Berdasarkan latar belakang masalah yang telah dipaparkan, maka rumusan masalah dalam penelitian ini adalah, “(a) Bagaimana gambaran konflik pekerjaan-keluarga pada wanita dengan peran ganda? (b) bagaimana gambaran kualitas hidup pada wanita peran ganda?, (c) bagaimana gambaran tingkat stres pada wanita dengan peran ganda? (d) Apakah stres dapat berperan sebagai mediator penghubung antara konflik pekerjaan-keluarga dan kualitas hidup pada wanita peran ganda?"

\section{METODE PENELITIAN}


Partisipan dalam penelitian ini berjumlah 183 partisipan dengan kriteria, 1) wanita, 2) menikah atau sudah pernah menikah, 3) memiliki anak. Peneliti merupakan sampel dari karyawan wanita peran ganda di Kementerian X. Teknik pemilihan sampel yang digunakan adalah non-probability. Peneliti menggunakan jenis purposive sampling dan convenience sampling. Peneliti menggunakan tiga alat ukur, sebagai berikut.

Multidimentional Scale of Work-Family Conflict. Instrumen pengukuran variabel konflik kerja-keluarga di adaptasi dari alat ukur Multidimentional Scale of WorkFamily Conflict yang disusun oleh Carlson et al. (2000). Pada awalnya, Greenhaus dan Bautell (1985) menyusun teori konflik kerja-keluarga dengan melakukan uji coba melalui kuesioner dengan partisipan dengan karakteristik yang berbeda, kemudian Carlson et al. (2000) mengembangkan alat ukur tersebut. Alat ukur tersebut disusun berdasar tiga dimensi yang telah dipaparkan sebelumnya, yakni, time-based conflict, strain-based conflict, dan behaviour-based conflict. Ketiga dimensi tersebut memiliki dua arah, yaitu work interferes with family dan family interferes with work (pekerjaan mengganggu keluarga dan keluarga mengganggu pekerjaan) sehingga berkembang menjadi enam dimensi, yaitu, time-based work interference with family, time-based family interference with work, strain-based work interference with family, strainbased family interference with work, behavioural-based work interference with family, dan behavioural-based family interference with work. Skala pengukuran yang digunakan adalah skala likert dengan skala angka 1 hingga 5, yaitu 1 untuk Sangat Tidak Setuju (STS), 2 untuk Tidak Setuju (TS), 3 untuk Ragu-ragu (RR), 4 untuk Setuju (S), dan skala 5 untuk Sangat Setuju (SS). Hasil dari alat ukur dilakukan dalam lima kategorisasi (Azwar, 2010), tyakni sangat tinggi, tinggi, sedang, rendah, dan sangat rendah. Pada alat ukur ini juga dilakukan construct validity dengan menggunakan confirmatory factor analysis second order dan juga construct reliability pada setiap dimensi pada aplikasi LISREL 8.80, terdapat 18 item yang memiliki nilai loading factor di atas 0.50 pada alat ukur ini sehingga keseluruhan item dapat digunakan untuk ke tahap selanjutnya.

World Health Organizational Quality Of Life (WHOQOL-BREF). Variabel kualitas hidup diukur dengan mengadaptasikan alat ukur yang diperoleh dari World Health Organization. Pengukuran variabel kualitas hidup menggunakan kuesioner WHOQOL-BREF yang terdiri dari 26 butir yang dibagi menjadi 2 pertanyaan general dan 24 butir yang mewakilkan 4 domain pada kualitas hidup, yaitu aspek kesehatan fisik, kesejahteraan psikologis, hubungan sosial, dan hubungan dengan lingkungan. Jumlah seluruh butir dari alat ukur ini adalah 23 butir positif dan 3 butir negatif. Penelitian ini menggunakan skala likert yang terdiri dari lima pilihan jawaban, yaitu seperti sangat buruk, buruk, biasa-biasa saja, baik, dan sangat baik. Pada kuesioner, diberikan penilaian skor 5 untuk sangat baik, skor 4 untuk baik, skor 3 untuk baikbaik saja, skor 2 untuk buruk, dan skor 1 untuk sangat buruk. Aspek kualitas hidup general yang akan mengungkapkan sejauh mana individu menilai kualitas kehidupannya saat ini. Semakin tinggi skor pada aspek ini, maka akan menandakan para perempuan peran ganda merasa puas dan merasa kehidupannya berkualitas. Pada alat ukur ini juga dilakukan construct validity dengan menggunakan confirmatory factor analysis second order dan juga construct reliability pada setiap dimensi pada aplikasi LISREL 8.80. Terrdapat 21 item yang memiliki nilai loading factor di atas 0.50 pada alat ukur ini sehingga 21 item tersebut dapat digunakan ke tahap selanjutnya. 
Alat Ukur Gejala Stres Umum. Kuesioner ini mengukur tiga dimensi dari stres. Pertama, dimensi fisik yang terkait dengan perubahan fisik yang dirasakan individu sebagai akibat dari stres. Pada dimensi fisik, terdapat 23 indikator yang mengukur gejala-gejala stres fisik. Contoh indikator, seperti "sakit kepala", "diare", dan "mualmual". Kedua, dimensi psikologis yang terkait dengan perubahan kondisi psikologis individu sebagai akibat dari stres. Pada dimensi psikologis terdapat 21 indikator yang mengukur gejala-gejala stres psikologis. Contoh indikatornya, seperti "cemas", "sulit berkonsentrasi", dan "panik". Ketiga, dimensi perilaku yang terkait dengan perubahan perilaku yang dialami individu sebagai akibat dari stres. Contoh indikatornya, seperti "nafsu makan menurun", "sering berbohong" dan "mengalami sulit tidur". Skala stres yang digunakan terdiri dari 62 butir pertanyaan berbentuk self report yang akan direspon dengan cara memberi tanda check. Tanda check yang diberikan pada setiap pernyataan akan diberikan nilai 1 , sedangkan pernyataan yang tidak diberikan tanda check akan diberikan nilai 0 . Peneliti juga melakukan construct validity untuk mengetahui apakah seluruh item yang terdapat pada alat ukur tersebut terbukti dapat mengukur konflik pekerjaan-keluarga. Pengujian construct validity ini menggunakan Confirmatory Factor Analysis (CFA) yaitu second order dengan menggunakan aplikasi Lisrel 8.7 dan terdapat 12 item yang berada pada loading factor di atas 0.50 .

\section{HASIL DAN PEMBAHASAN}

\section{HASIL}

Seluruh data dalam penelitian ini diolah dengan melihat nilai rata-rata empirik dari para partisipan. Hasil dari alat ukur Multidimentional Scale of Work-Family Conflict didapatkan nilai mean empirik sebesar 3.066 dengan nilai standar deviasi 0.544. Melalui data tersebut, peneliti dapat membuat kategori konflik pekerjaan-keluarga partisipan, dengan hasil sebagai berikut:

Tabel 1. Gambaran Umum Konflik Pekerjaan-Keluarga

\begin{tabular}{lllllll}
\hline & Sangat Tinggi & Tinggi & Sedang & Rendah & $\begin{array}{l}\text { Sangat } \\
\text { Rendah }\end{array}$ & Total \\
\hline $\begin{array}{l}\text { Konflik } \\
\begin{array}{l}\text { Pekerjaan- } \\
\text { Keluarga }\end{array}\end{array}$ & 11 & 47 & 78 & 30 & 17 & 183 \\
\hline
\end{tabular}

Berdasarkan hasil pada tabel 1, dapat dilihat bahwa para wanita peran ganda yang menjadi partisipan dalam penelitian ini mayoritas memiliki konflik pekerjaankeluarga pada tingkat sedang. Lebih lanjut, peneliti juga membandingkan nilai rerata dari seluruh dimensi konflik pekerjaan-keluarga, dengan hasil sebagai berikut:

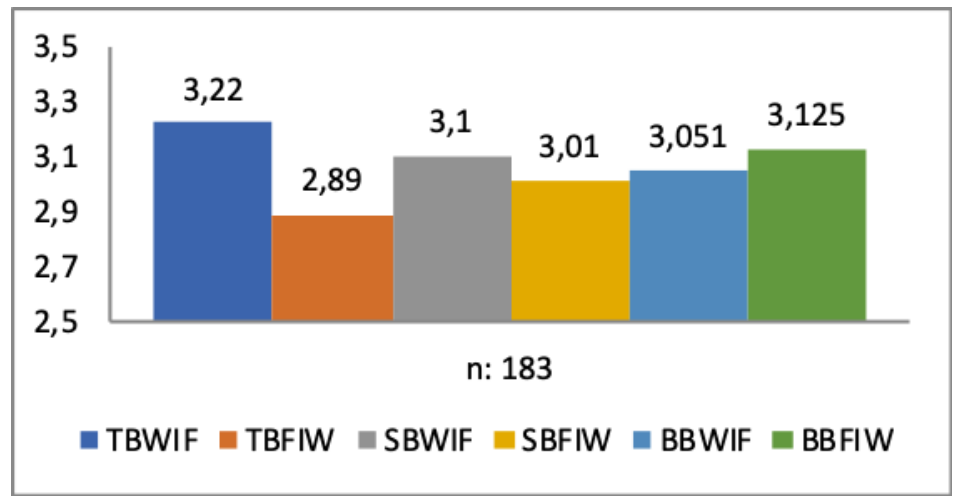

Gambar 1. Rerata Dimensi Konflik Pekerjaan-Keluarga 
Melalui gambar 1, juga dapat terlihat bahwa dimensi TBWIF atau time-based work interference with family memiliki nilai rerata yang paling tinggi, yaitu 3.22. Hal ini mengindikasikan bahwa partisipan cenderung kurang mampu membagi waktu dalam menjalankan tuntutan pekerjaan sehingga mengurangi waktu bersama keluarga.

Hasil dari alat ukur WHOQOL-BREF yang diberikan untuk mengetahui kategori kualitas hidup partisipan, didapatkan nilai mean empirik sebesar 2.58 dengan nilai standar deviasi 0.502. Melalui data tersebut, peneliti dapat membuat kategori kualitas hidup partisipan, dengan hasil sebagai berikut:

Tabel 2. Gambaran Umum Kualitas Hidup

\begin{tabular}{lllllll}
\hline & Sangat Tinggi & Tinggi & Sedang & Rendah & Sangat Rendah & Total \\
\hline Kualitas & $\mathrm{n}: 16$ & $\mathrm{n}: 39$ & $\mathrm{n}: 67$ & $\mathrm{n}: 51$ & $\mathrm{n}: 10$ & $\mathrm{n}: 183$ \\
Hidup & $(8.7 \%)$ & $(21.3 \%)$ & $(36.6 \%)$ & $(27.9 \%)$ & $(5.5 \%)$ & $(100 \%)$ \\
\hline
\end{tabular}

Berdasarkan hasil kategorisasi data penelitian, dapat dilihat pada tabel 2, mayoritas partisipan berada pada kategori sedang. Hal ini menunjukkan bahwa partisipan di Kementerian $\mathrm{X}$ merasa cukup puas dengan fisik, psikologis, hubungan dengan lingkungan, dan juga hubungan dengan orang lain di sekitar partisipan.

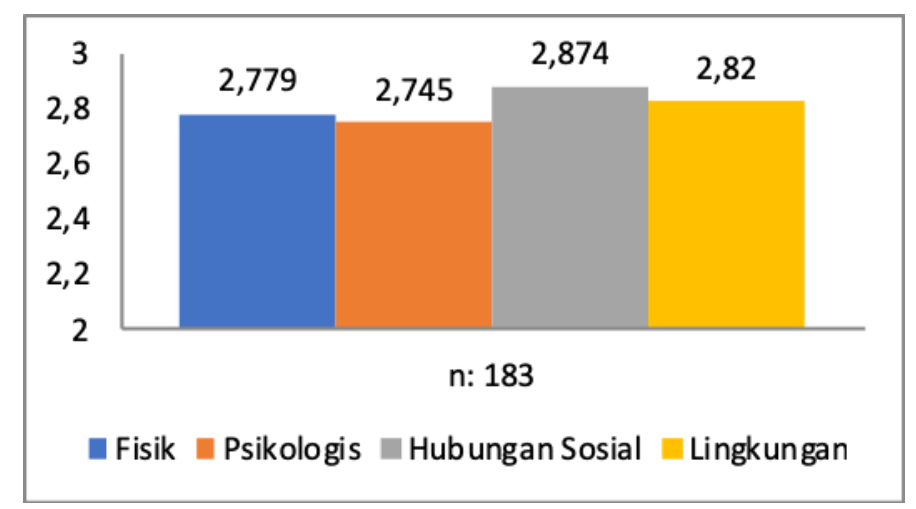

Gambar 2. Rerata Dimensi Kualitas Hidup

Berdasarkan hasil kategorisasi data penelitian, diketahui terlihat bahwa dimensi kualitas hidup hubungan dengan lingkungan merupakan dimensi yang memiliki nilai paling tinggi. Hal ini mengindikasikan bahwa partisipan merasakan kepuasan terhadap aspek lingkungannya, seperti tempat tinggal, keamanan, pelayanan, keuangan, dan lainnya. Selain itu, nilai yang paling rendah adalah nilai rerata pada dimensi psikologis. Hal ini mengindikasikan bahwa, partisipan kurang puas dengan aspek psikologis yang berada dalam diri partisipan.

Hasil dari alat ukur Gejala Stres Umum yang diberikan untuk mengetahui kategori stres partisipan, didapatkan nilai mean empirik sebesar 0.273 dengan nilai standar deviasi 0.171 . Melalui data tersebut, peneliti dapat membuat kategori stres partisipan, dengan hasil sebagai berikut: 
Tabel 3. Gambaran Umum Stres

\begin{tabular}{lcccccc}
\hline & $\begin{array}{c}\text { Sangat } \\
\text { Tinggi }\end{array}$ & Tinggi & Sedang & Rendah & $\begin{array}{c}\text { Sangat } \\
\text { Rendah }\end{array}$ & Total \\
\hline Stres & 17 & 43 & 42 & 34 & 47 & 183 \\
& $(9.3 \%)$ & $(23.5 \%)$ & $(22.9 \%)$ & $(18.6 \%)$ & $(25.7 \%)$ & $(100 \%)$ \\
\hline
\end{tabular}

Berdasarkan hasil kategorisasi data penelitian, dapat dilihat pada tabel 3, dapat dilihat bahwa para wanita peran ganda yang menjadi partisipan dalam penelitian ini memiliki tingkat stres yang cukup menyebar. Lebih lanjut, peneliti juga membandingkan nilai rerata dari seluruh dimensi stres, dengan hasil sebagai berikut:

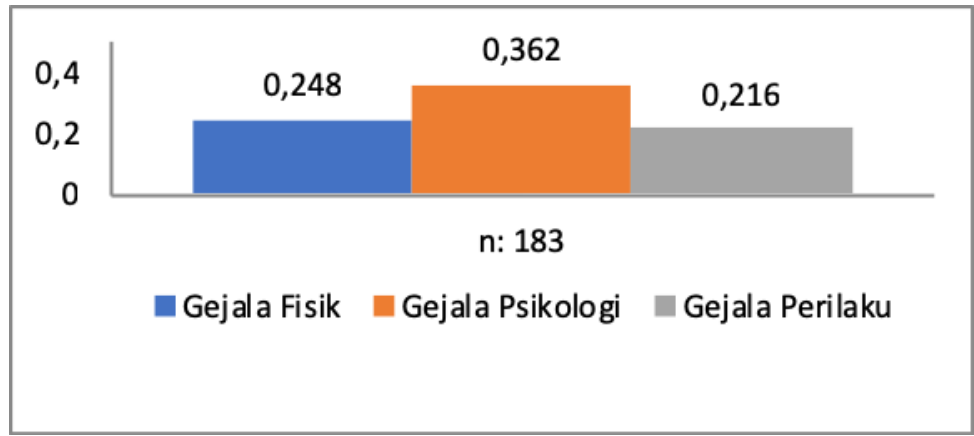

Gambar 3. Rerata Dimensi Stres

Berdasarkan hasil kategorisasi data penelitian, diketahui bahwa gejala stres psikologis memiliki nilai rerata yang paling tinggi yang mengindikasikan bahwa gejala psikologis merupakan gejala stres yang paling sering dialami oleh partisipan.

Hasil Uji Hipotesis. Untuk dapat menjawab hipotesis dalam penelitian ini, peneliti melakukan uji structural model dengan menggunakan aplikasi LISREL 8.80 dengan Structural Equation Modelling (SEM) seperti gambar di bawah ini:

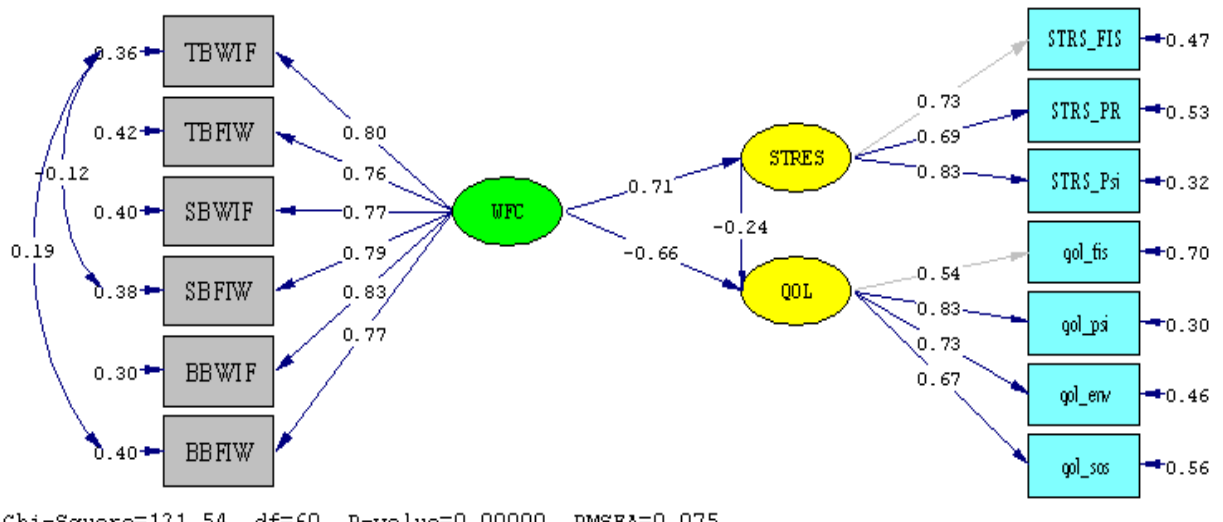

Gambar 4. Path Diagram SEM (standardized solution) 


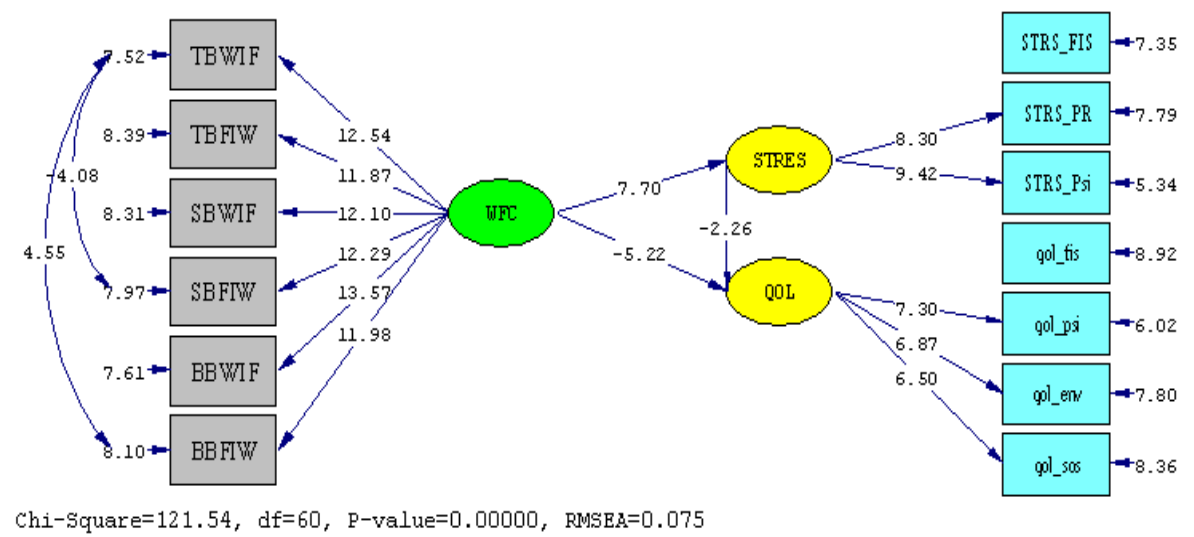

Gambar 5. Path Diagram SEM ( $t$-values)

Berdasarkan nilai RMSEA sebesar 0,000 ( $P$-value tidak mencapai 0.05) dapat dikatakan model fit dengan data empiris. Melalui hasil perhitungan SEM di atas, dapat diketahui hasil struktural model untuk menjawab hipotesis yang menjadi pertanyaan dalam penelitian.

\begin{tabular}{|c|c|c|c|}
\hline Input: & & Test statistic: & p-value: \\
\hline$t_{a} 7.70$ & Sobel test: & 2.16852445 & 0.03011881 \\
\hline \multirow[t]{3}{*}{$t _ { \mathrm { b } } \longdiv { - 2 . 2 6 }$} & Aroian test: & 2.15188104 & 0.03140672 \\
\hline & Goodman test: & 2.18556011 & 0.0288478 \\
\hline & Reset all & \multicolumn{2}{|c|}{ Calculate } \\
\hline
\end{tabular}

Gambar 6. Hasil Uji Sobel Test

Pada hasil Sobel test diatas, dapat dilihat bahwa didapatkan nilai t-test Sobel test sebesar 2.168 dengan kriteria ( $t$-value $>1.96)$ maka dapat dikatakan variabel mediator dalam penelitian ini, terbukti dapat menjadi mediator. Selanjutnya, jika dilihat melalui nilai $p$-value Sobel test, juga didapatkan nilai sebesar 0.0301 dengan kriteria (p-value < 0.05) yang dapat menyatakan bahwa stres dalam penelitian ini, dapat berfungsi secara sempurna sebagai mediator.

Tabel 4. Tabel Perhitungan Model Struktural

\begin{tabular}{llllc}
\hline Model Struktural & Koefisien & $\begin{array}{l}\text { Direct Effects } \\
\text { (standardized) }\end{array}$ & $\begin{array}{l}\text { Indirect Effects } \\
\text { (standardized) }\end{array}$ & Total \\
\hline $\begin{array}{l}\text { Konflik Pekerjaan- Keluarga - } \\
\rightarrow \text { Kualitas Hidup }\end{array}$ & -0.66 & -0.66 & - & -0.66 \\
$\begin{array}{l}\text { Konflik Pekerjaan- } \\
\text { Keluarga } \rightarrow \text { Stres }\end{array}$ & 0.71 & & - & - \\
Stres $\rightarrow$ Kualitas Hidup & -0.24 & & -0.17 & -0.17 \\
& & $\begin{array}{l}\text { (pembulatan } \\
\text { Total }\end{array}$ & & $0.1704)$ \\
\end{tabular}

Melalui hasil tabel 4, dapat dilihat bahwa stres memiliki hubungan sebesar -0.17 kepada peran konflik pekerjaan-keluarga dan kualitas hidup. Peranan konflik pekerjaan-keluarga terhadap kualitas hidup yang semula hanya sebesar -0.66 berkurang menjadi -0.83 dengan adanya sumbangan dari variabel mediator, yaitu stres. Hal ini mengindikasikan bahwa partisipan yang mengalami konflik pekerjaan- 
keluarga, kualitas hidup partisipan tersebut akan rendah, dan ketika partisipan yang mengalami konflik pekerjaan-keluarga dan juga stres, kualitas hidupnya akan menjadi semakin rendah.

\section{Pembahasan}

Hasil dalam penelitian ini stres pada partisipan berada pada kategori sedang. Pada penelitian Howatt \& Amell (2018), dikatakan bahwa stres dalam kategorisasi sedang, dapat membantu dalam meningkatkan performa dan produktivitas kerja. Sehingga dapat dikatakan bahwa pekerja dalam kategori stres sedang merupakan pekerja yang produktif dan bertanggung jawab akan pekerjaannya. Lebih lanjut Howatt \& Amell (2018) menjelaskan bahwa pada kadar tinggi, stres cenderung dapat menimbulkan dampak negatif seperti rasa cemas, tidak bahagia dan penurunan performa kerja. Sedangkan pada kadar rendah, stres dapat memicu adanya perasaan bosan dan juga menurunkan performa kerja.

Dari keseluruhan partisipan yang mengalami stres, terdapat 60 partisipan atau $32.8 \%$ dari jumlah sampel yang memerlukan penanganan karena berada pada kategori tinggi dan memerlukan penanganan lebih lanjut. Hasil penelitian ini juga didukung oleh penelitian Amalia (2001) bahwa wanita dengan peran ganda, dengan peran sebagai karyawan dan ibu rumah tangga, akan lebih mudah mengalami stres daripada wanita yang belum menikah. Selain itu penelitian Anastasia (2011) juga menjelaskan bahwa wanita peran ganda tidak mampu mengatasi stres yang dialami dikarenakan tuntutan berprestasi dari tempat kerja, maupun tuntutan untuk meningkatkan finansial dalam hidupnya.

Pada partisipan secara umum, diketahui bahwa gejala stres yang paling tinggi adalah gejala stres psikologis, dibandingkan dengan gejala stres fisik dan perilaku. Hal tersebut mengindikasikan bahwa pada partisipan penelitian, lebih sering mengalami gejala psikologis dari stres dibandingkan gejala fisik dan perilaku. Hal ini juga terkait dengan pekerjaan pegawai negeri sipil yang cenderung monoton dan melakukan deskripsi kerja yang sama setiap harinya. Hasil penelitian ini juga didukung oleh penelitian yang dilakukan oleh Greenhaus dan Beutell (1985) bahwa karyawan yang bekerja secara subjektif maupun objektif bekerja dengan jenis pekerjaan yang monoton dan terus menerus, memiliki kecenderungan untuk mengalami tekanan psikologis, seperti kecemasan, emosi naik turun, dan mudah marah.

Selanjutnya, peneliti melakukan perbandingan pada konflik pekerjaan-keluarga terhadap stres, partisipan yang mengalami konflik pekerjaan-keluarga dengan kategori tinggi (n:58), terlihat bahwa partisipan yang mengalami stres tinggi adalah 49 partisipan. Hal ini mengindikasikan bahwa ketika partisipan mengalami konflik pekerjaan-keluarga dengan kategori tinggi, maka partisipan akan mengalami stres dengan kategori yang tinggi.. Penemuan ini sejalan dengan penelitian yang dilakukan oleh Dhamayanti (2013) bahwa konflik yang berkepanjangan tidak hanya dapat menurunkan kinerja tapi bisa menimbulkan stres yang menimbulkan dampak lebih yaitu ketidakseimbangan fisik dan psikis sebagai bentuk reaksi terhadap tekanan.

Pada variabel kualitas hidup, dimensi terendah terdapat pada dimensi psikologis. Hal ini mengindikasikan bahwa partisipan kurang puas akan kondisi psikologisnya. Power (2003) mengatakan bahwa kondisi psikologis merupakan salah satu faktor penting yang dapat mempengaruhi kualitas hidup. Sesuai dengan hasil penelitian, bahwa 
dimensi psikologis merupakan dimensi dengan nilai rata-rata yang paling rendah, dibandingkan dengan dimensi fisik, lingkungan, dan hubungan sosial. Dimensi psikologis merupakan gambaran mental individu yang mengarah pada kemampuan individu dalam menyesuaikan diri terhadap tuntutan dalam diri maupun luar diri. Hasil ini juga sejalan dengan penelitian yang dilakukan oleh Skevington, Lotfy, dan O'Connell (2004) bahwa dimensi psikologis dan sosial menunjukkan hasil yang berbeda, dan menunjukkan bahwa wanita memiliki kualitas hidup psikologis yang lebih buruk dibandingkan dengan para pria.

Hasil penelitian ini menunjukkan adanya peranan konflik pekerjaan-keluarga terhadap stres, adanya peranan stres terhadap kualitas hidup, adanya peranan konflik pekerjaan-keluarga terhadap kualitas hidup, dan juga stres sebagai variabel intervening berhasil dalam memediasi hubungan konflik pekerjaan-keluarga dengan kualitas hidup. Hasil yang didapatkan pada gambaran penelitian juga sangat sesuai dengan uji model yang dilakukan dalam penelitian ini, di mana seluruh hipotesis penelitian diterima atau dengan kata lain, model dalam penelitian ini sesuai dan fit yang didukung oleh hasil Structural Equation Model.

\section{KESIMPULAN DAN SARAN}

\section{Kesimpulan}

Berdasarkan hasil penelitian, dapat disimpulkan bahwa konflik pekerjaan-keluarga, stres, dan kualitas hidup pada karyawan di Kementerian $\mathrm{X}$ berada pada kategori sedang. Melalui hasil uji model, juga dapat diketahui bahwa stres dapat memberikan sumbangan dan mampu meningkatkan peran konflik pekerjaan-keluarga terhadap kualitas hidup, sehingga dapat dinyatakan bahwa stres mampu menjadi variabel mediator di antara peran konflik pekerjaan-keluarga terhadap kualitas hidup. Maka kesimpulan dari hasil penelitian ini adalah konflik pekerjaan-keluarga memiliki peran terhadap kualitas hidup pada wanita peran ganda, namun peran tersebut akan lebih besar saat wanita peran ganda juga mengalami stres ketika menemukan konflik pekerjaan-keluarga. Oleh karena itu, wanita peran ganda yang telah mengalami konflik pekerjaan-keluarga harus dapat mengatasi dan mengontrol diri dari konflik pekerjan dan konflik keluarga agar tidak menurunkan kualitas hidupnya.

\section{Saran}

Saran untuk penelitian selanjutnya. Mempertimbangkan terbatasnya penelitian, peneliti selanjutnya dapat mengkaji konflik pekerjaan-keluarga pada profesi lainnya ataupun mengkaji mengenai konflik pekerjaan-keluarga di perusahaan swasta agar mendapatkan informasi lebih beragam, dengan mempertimbangkan hal di bawah ini, (1) melakukan kontrol terhadap seluruh faktor yang dapat memengaruhi variabel penelitian, seperti kondisi kerja, gaji partisipan, maupun faktor kepribadian yang dapat memengaruhi variabel penelitian, (2) sebaiknya rancangan intervensi dapat diuji kelayakan dan keakuratannya melalui metode eksperimen murni, agar dapat memberikan tindakan preventif langsung untuk mengurangi dampak konflik pekerjaan-keluarga, mengurangi stres serta dapat meningkatkan kualitas hidup partisipan dan dapat menghindari gangguan psikologis.

Saran Praktis bagi Kementerian. Berdasarkan hasil penelitian, terdapat beberapa kebijakan dan pertimbangan akan beberapa hal yang tidak dapat diubah dari peraturan 
Kementerian X, maka saran yang diberikan peneliti, yaitu, (1) memberikan psikoedukasi mengenai dampak stres maupun dampak konflik pekerjaan-keluarga atau memberikan workshop dan intervensi kelompok guna untuk memperbaiki aspek kerja dan keluarga partisipan, (2) meningkatkan work family balance ke dalam core values manajemen Kementerian dengan cara menjalin komunikasi dua arah yang positif. Pihak atasan diharapkan lebih komunikatif untuk menanyakan kondisi keluarga bawahan agar terciptanya kenyamanan dalam bekerja.

Saran Praktis bagi Karyawan Wanita Peran Ganda. Permasalahan pada penelitian ini adalah konflik pekerjaan-keluarga yang akhirnya menimbulkan stres dan berdampak pada kualitas hidup wanita peran ganda. Oleh sebab itu, untuk menghindari stres, penting untuk membangun keseimbangan antara pekerjaan dan keluarga, seperti menyusun skala prioritas dan tidak menyampingkan salah satu peran, sehingga tuntutan dalam kedua peran dapat terpenuhi secara efisien dan sumber daya yang dibutuhkan dapat tercapai. Untuk meminimalkan permasalahan dalam keluarga, wanita peran ganda dapat meningkatkan komunikasi yang baik dengan pasangan ataupun meluangkan waktu untuk pergi berlibur bersama keluarga. Sedangkan, untuk meminimalkan permasalahan di tempat kerja, para wanita peran ganda diharapkan untuk memenuhi tugas-tugas pekerjaan dengan tepat waktu, melakukan penjadwalan, menyusun skala prioritas, dan memiliki dukungan sosial yang baik di tempat kerja sehingga permasalahan dalam pekerjaan maupun keluarga dapat terminimalisir dengan baik.

\section{Ucapan Terima Kasih}

Penulis mengucapkan terima kasih kepada semua pihak yang telah memberikan dukungan sehungga artikel ini dapat disusun dengan baik.

\section{REFERENSI}

Alteza, M,. \& Hidayati, L.N. (2009). Work-family conflict pada wanita bekerja: studi tentang penyebab, dampak dan strategi coping. Yogyakarta: Fakultas Ilmu Sosial dan Ekonomi Universitas Negeri Yogyakarta.

Amstad, F.T., Meier, L.L., Fasel, U., Elfering, A., \& Semmer, N.K. (2011). A Meta analysis of work-family conflict and various outcomes with a special eEmphasis on crossdomain versus matching-domain relations. Journal of Occupational Health Psychology, $16(2)$, p.151.

Anastasia. (2011). Hubungan Kecerdasan Emosi Dengan Konflik Peran Ganda pada Karyawan Wanita BRI ( Bank Rakyat Indonesia) Yogyakarta. (Skripsi). Fakultas Psikologi. Universitas Kristen Satya Wacana.

Apperson, M., Schmidt, H., Moore, S., \& Grunber, L. (2002). Women managers and the experience of work-family conflict. American Journal of Undergraduate Research, $1(3)$.

Apollo, A. (2012). Konflik peran ganda perempuan menikah yang bekerja ditinjau dari dukungan sosial keluarga dan penyesuaian diri. Jurnal Widya Warta. Fakultas Psikologi, Universitas Katolik Widya Mandala Madiun, 4(2), 65-72.

Ardila, I, \& Sulistyaningsih, D. R., (2014). Hubungan tingkat stres dengan kualitas hidup pasien penyakit ginjal kronik yang menjalani hemodialisa di rumah sakit umum daerah kota semarang. Jurnal Keperawatan dan Kebidanan, 1 (10), 569- 577.

Baron, R. M., \& Kenny, D. A. (1986). The moderator-mediator variable distinction in social psychological research: conceptual, strategic, and statistical considerations. Journal of Personality and Social Psychology, 51 (6), 3-28. 
Carlson, Dawn S., Kacmar, K. Michele, \& Williams, Larry J. (2000). Construction and initial validation of a multidimensional measure of work-family conflict. Journal of Vocational Behavior, 56(2).

Dhamayanti, E. (2013). Kecerdasan spiritual, work family conflict, family work conflict dan kinerja pada pekerjaan dan keluarga (studi pada karyawan perbankan di Surabaya), Jurnal BPPK, 6 (1), pp. 41-48.

Frone, M,R., M Russell, M dan M.L Cooper. (1992). Antecedent and Outcomes Work Family Conflict : Testing a Model of the Work Family Interface. Journal of Applied Psychology, 77 (1), pp. 65-78.

Frone, M. R. (2000). Work-family conflict and employee psychiatric disorders: The National Comorbidity Survey. Journal of Applied Psychology, 85, 888-895

Galinsky, E., Bond, J. T., \& Friedman, D. E. (1996). The role of employers in addressing the needs of employed parents. Journal of Social Issues, 52, 111-136.

Greenhaus, J.H., \& Beutell, N.J. (1985). Sources of counflic between work and family roles. The Academy of Management Review, 1(10), 76-88.

Hawari, D. (2008). Manajemen Stres, Cemas, dan Depresi. Jakarta : FKUI.

Hayasaka, Y., Nakamura, K., Yamamoto, M., Sasaki, S. (2007). Work environtment and mental health status asseses by the general health questionnaire in female Japanese doctors. Industrial Health Journal, 45, 781-786.

Hermayanti, D. (2014). Kebermaknaan hidup dan konflik peran ganda pada wanita karier yang berkeluarga di kota samarinda. Journal Psikologi. 2(3), 269- 278.

Hultman, B., Hemlin, S., \& Hornquist, J. O. (2006). Quality of life among unemployed and employed people in northern Sweden. Are there any differences?. A Journal of Prevention, Assessment and Rehabilitation, 26(1).

ILO. (2011). Mempromosikan kesetaraan gender dalam dunia kerja "Kegiatan pengarusutamaan gender ILO-Jakarta”. Publikasi. Jakarta: ILO Country Office For Indonesia and Timor Leste.

ILO. (2015). Tren ketenagakerjaan dan sosial di Indonesia 2014 - 2015: Memperkuat daya saing dan produktivitas melalui pekerjaan layak/Kantor Perburuhan Internasional. Jakarta.

Ismanto, A., \& Suhartini, E. (2014). Beban Ganda Wanita Karir di PT.PJB UP Paiton. Artikel Ilmiah Hasil Penelitian Mahasiswa, I (1), 1-5.

Lopez, \& Snyder, C.R. (2003). Positive Psychological Assessment a Handbook of Models \& measures. Washington. DC : APA.

Maherani, A. (2008). Pengaruh Konflik Peran Ganda Dan Fear of Succes IK Terhadap Wanita Berperan (Tesis). Universitas Gunadarma,Jakarta.

Poms, L. W., Fleming, L. C., \& Jacobsen, K. H. (2016). Work-family conflict, stress, and physical and mental health: A model for understanding barriers to and opoportunities for womens well-being at home and in the workplace. World medical and health policy, 444-471.

Putri, N. E., Kholis, F. N., Ngestiningsih, D. (2018). Hubungan tingkat stres dan kualitas hidup pada pasien tuberkolosis di rsup dr. kariadi semarang. Jurnal Kedokteran Diponegoro. 7 (2), 499-506.

Renwick, R, \& Brown, I. (1996). Quality of Life in Health Promotion and Rehabilitaton. California. Sage Publication, Inc.

Rice, R. W., Frone, M. R., McFarlin, D. B. (1992). Work-nonwork conflict and the perceived quality of life. Journal of Organizational Behavior, vol. 13, 155-168.

Sidhawati, D. P. I., \& Syarifah, D. (2014). Hubungan antara perceived organizational support dengan work family conflict pada wanita karier di industri perbankan surabaya. Jurnal Psikologi Industri dan Psikologi, 3 (3), 169-175.

Urbayatun. S., \& Widhiarso. (2012). Variabel mediator dan moderator dalam penelitian psikologi kesehatan masyarakat. Jurnal Psikologi, 39(2),180- 188.

World Health Organization. (1996) The world health report 1996: fighting diease-fostering development. Geneva: WHO. 
Wirakristama, R. C. (2011). Analisis Pengaruh Konflik Peran Ganda (Work Family Conflict) Terhadap Kinerja Karyawan Wanita Pada PT Nyonya Meneer Semarang dengan STRES kerja Sebagai Variabel Intervening. Skripsi (tidak diterbitkan). Semarang : Fakultas Ekonomi Universitas Diponegoro.

Yang, N., Chen, C. C., \& Zou, Y. (2000). Sources of work-family conflict; A Sino-US comparison of the effects of work and family demands. Journal of Academy Management, 43(1), 113-123. 